Article

\title{
Imine-linked conjugated organic polymer bearing bis(imino)pyridine ligands and its catalytic application in $\mathrm{C}-\mathrm{C}$ coupling reactions
}

\author{
Guifu Chen a,b, Feng Wang a,*, Yehong Wang a, Xiaochen Zhang a, Hongqiang Qin a, Hanfa Zou a, \\ Jie $\mathrm{Xu}^{\mathrm{a}, \#}$ \\ a Dalian Institute of Chemical Physics, Chinese Academy of Sciences, Dalian 116023, Liaoning, China \\ ${ }^{\mathrm{b}}$ Graduate University of Chinese Academy of Sciences, Beijing 100049, China
}

\section{A R T I C L E I N F O}

\section{Article history:}

Received 1 November 2013

Accepted 6 January 2014

Published 20 April 2014

Keywords:

Conjugated organic polymer material

Bis(imino)pyridine ligand

Catalysis

Suzuki-Miyaura C-C coupling

\begin{abstract}
A B S T R A C T
Covalent organic polymers are an emerging class of materials with potential applications in areas including molecular separation, gas sorption, and catalysis. A novel fully conjugated organic polymer bearing bis(imino)pyridine (COP-BIP) and its catalytic function are reported here. Unlike previous $\mathrm{COP}$ materials, the imine bonds of COP-BIP act as both linkages and complexation sites for the binding of metal ions. A clear structure is presented based on ultraviolet-visible, Fourier transform infrared, and matrix-assisted laser desorption/ionization time-of-flight mass spectrometry characterization. The COP-BIP materials are thermally stable up to $440^{\circ} \mathrm{C}$ and are insoluble in conventional solvents. In addition, COP-BIP complexes Pd ions on bis(imino)pyridine sites and forms a heterogeneous catalyst, which exhibits excellent catalytic activity in the Suzuki-Miyaura C-C coupling reaction.
\end{abstract}

(C) 2014, Dalian Institute of Chemical Physics, Chinese Academy of Sciences. Published by Elsevier B.V. All rights reserved.

\section{Introduction}

Covalent organic polymers are an emerging class of materials with potential applications in areas such as molecular separation, gas sorption, and catalysis [1,2]. The successful design and synthesis of these polymers linked by B-O [3-5], C-C [6,7], $\mathrm{C}-\mathrm{N}$ [8], and $\mathrm{C}=\mathrm{N}$ [9-12] bonds have been reported. Recent studies have shown that conjugated organic polymers (COPs) with extended $\pi$-conjugation possess high thermal stability and structure diversity [13-15]. However, the synthesis of these COP materials usually requires expensive precursors and intricate techniques. Further modification of these COPs for practi- cal use is difficult because of limited synthetic diversification. Although nuclear magnetic resonance techniques have been employed, the precise chemical structures of COPs are mostly unknown. For catalytic applications, it is desirable that COP materials should be stable toward heat, air, and solvents, and be designable.

In organometallic chemistry a wide range of ligands have been used to bind metals, and bis(imino)pyridines ligands are among the most common (Scheme 1). This is presumably because of their relatively facile functionalization, stability and ability to bind a large number of transition metal ions ( $d$ and $f$ blocks) [16-20]. With advantages of separation, recycling, and

\footnotetext{
* Corresponding author. Tel/Fax: +86-411-84379762; E-mail: wangfeng@dicp.ac.cn

\# Corresponding author. Tel/Fax: +86-411-84379245; E-mail: xujie@dicp.ac.cn

This work was supported by the National Natural Science Foundation of China $(21073184,21273231)$ and Hundred Talents Program of the Chinese Academy of Sciences.
}

DOI: 10.1016/S1872-2067(14)60021-8 | http://www.sciencedirect.com/science/journal/18722067 | Chin. J. Catal., Vol. 35, No. 4, April 2014 


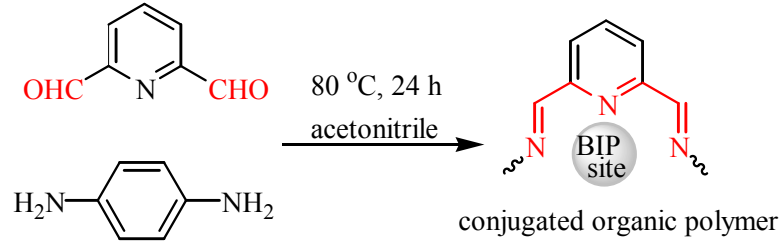

Scheme 1. Synthesis of the COP-BIP material.

reuse, heterogeneous catalysts are widely used in the production of chemicals. To date the use of COPs as catalytic materials is rare. We thus investigated the incorporation of bis(imino)pyridine ligands into COPs to prepare solid catalysts upon coordination with metal ions. Herein we report, for the first time, a method of preparing bis(imino)pyridine-containing conjugated polymers (COP-BIP) based on Schiff-base chemistry. The COP-BIP material was highly stable up to $440{ }^{\circ} \mathrm{C}$ and was insoluble in water and aprotic solvents. The bis(imino)pyridine ligands, as binding sites, formed complexes with $\mathrm{Pd}$ ion to give a heterogeneous catalyst, which demonstrated excellent catalytic activity in a classic Suzuki-Miyaura reaction. We also show that matrix-assisted laser desorption/ionization time-of-flight (MALDI-TOF) mass spectroscopy is a direct and reliable method for the determination of the COP structure.

\section{Experimental}

The COP-BIP material was prepared from the reaction between 2,6-pyridinedicarboxaldehyde and 1,4-diamine benzene at $80{ }^{\circ} \mathrm{C}$ in acetonitrile via an imination reaction with the elimination of water, as shown in Scheme 1. The mixture became yellow and then turbid. At $24 \mathrm{~h}$, a precipitate had formed and was collected by centrifugation. A small amount of acetic acid can remarkably accelerate the reaction, but it was not used in our synthesis so that a pure material could be obtained. Solvents such as methanol, ethanol, dimethylformamide, and dimethyl sulfoxide were used and gave identical materials.

A Suzuki-Miyaura cross-coupling reaction was carried out as follows. About $0.5 \mathrm{mmol}$ 4-bromoanisole in $1 \mathrm{~mL}$ ethanol (HPLC grade), $0.75 \mathrm{mmol}$ phenylboronic acid in $1 \mathrm{~mL}$ ethanol, $1.0 \mathrm{mg} \mathrm{PdCl} / \mathrm{COP}-\mathrm{BIP}$, and $0.1 \mathrm{mmol} \mathrm{K}_{2} \mathrm{CO}_{3}$ were added sequentially into a $5 \mathrm{~mL}$ vial and stirred at $50{ }^{\circ} \mathrm{C}$ for $3 \mathrm{~h}$. The conversion of 4-bromoanisole was determined by gas chromatography using a calibration curve.

\section{Results and discussion}

Monitoring the reaction by time-dependent liquid ultraviolet-visible (UV-Vis) spectroscopy showed that the C=N absorption at $375 \mathrm{~nm}$ constantly increased (Fig. 1), indicating that the reaction between $-\mathrm{CHO}$ and $-\mathrm{NH}_{2}$ was consistent with that reported in the literature wherein the bright yellow color was due to the $\mathrm{C}=\mathrm{N}$ chromophore [10].

The successful build-up of a conjugated polymer was confirmed by Fourier transform infrared (FT-IR) spectroscopy (Fig. 2). A strong vibration at $1623 \mathrm{~cm}^{-1}$ clearly indicated the

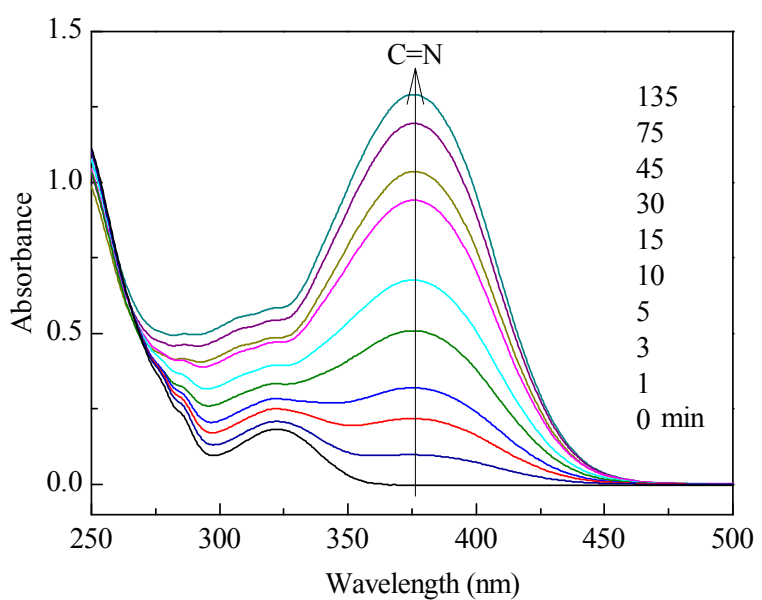

Fig. 1. Monitoring the formation of the $\mathrm{C}=\mathrm{N}$ bond during the synthesis at $375 \mathrm{~nm}$ by liquid-phase UV-Vis spectroscopy.

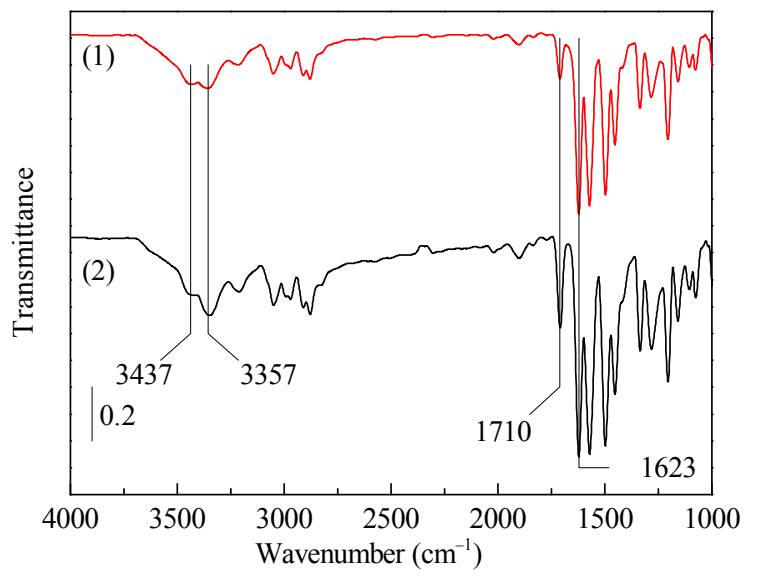

Fig. 2. FT-IR spectra of the COP-BIP material. (1) Freshly synthesized material dried at $110^{\circ} \mathrm{C}$ in air for $2 \mathrm{~h}$; (2) Treated at $250{ }^{\circ} \mathrm{C}$ in $\mathrm{H}_{2}$ for $2 \mathrm{~h}$.

formation of imine bonds $(\mathrm{C}=\mathrm{N})$. The aldehyde $(\mathrm{C}=\mathrm{O})$ peak at $1710 \mathrm{~cm}^{-1}$ and the two broad bands at 3437 and $3357 \mathrm{~cm}^{-1}$ assigned to unreacted $-\mathrm{NH}_{2}$ suggested the co-existence of terminal $-\mathrm{CHO}$ groups and $-\mathrm{NH}_{2}$ groups.

The conjugated polymer exhibited high stability as evidenced by thermal gravimetric analysis (TGA). As shown in Fig. 3 , an apparent decomposition (weight loss of approx. 3\%) occurred at $440{ }^{\circ} \mathrm{C}$ in $\mathrm{N}_{2}$ and at $420{ }^{\circ} \mathrm{C}$ in air. These results indicate that COP-BIP is more stable than other covalent organic polymers such as triazine-based frameworks (about $410{ }^{\circ} \mathrm{C}$ in air) [20], melamine-based polymer (about $400{ }^{\circ} \mathrm{C}$ in $\mathrm{N}_{2}$ ) [8], COF-LZU1 (about $310^{\circ} \mathrm{C}$ in $\mathrm{N}_{2}$ ) [2], and POFs (about $400{ }^{\circ} \mathrm{C}$ in $\mathrm{N}_{2}$ ) [10]. By comparison, a polymer with a $\mathrm{N}, \mathrm{O}, \mathrm{N}$ unit [21], which is different to the N,N,N unit of COP-BIP, is stable at 300 ${ }^{\circ} \mathrm{C}$ in $\mathrm{N}_{2}$. The imine can be reduced to the amine by hydrogenation. A test conducted in $\mathrm{H}_{2}$ at $250{ }^{\circ} \mathrm{C}$ found no apparent change in structure as observed by IR (Fig. 2). Therefore, COP-BIP was very stable under both oxidative and reductive conditions. We conclude that the high stability of COP-BIP arises from the bis(imino)pyridine sites and the fully conjugated structure.

COP-BIP is insoluble in conventional solvents such as hydrocarbons, alcohols, ketones, nitriles, amides, and sulfoxides. 

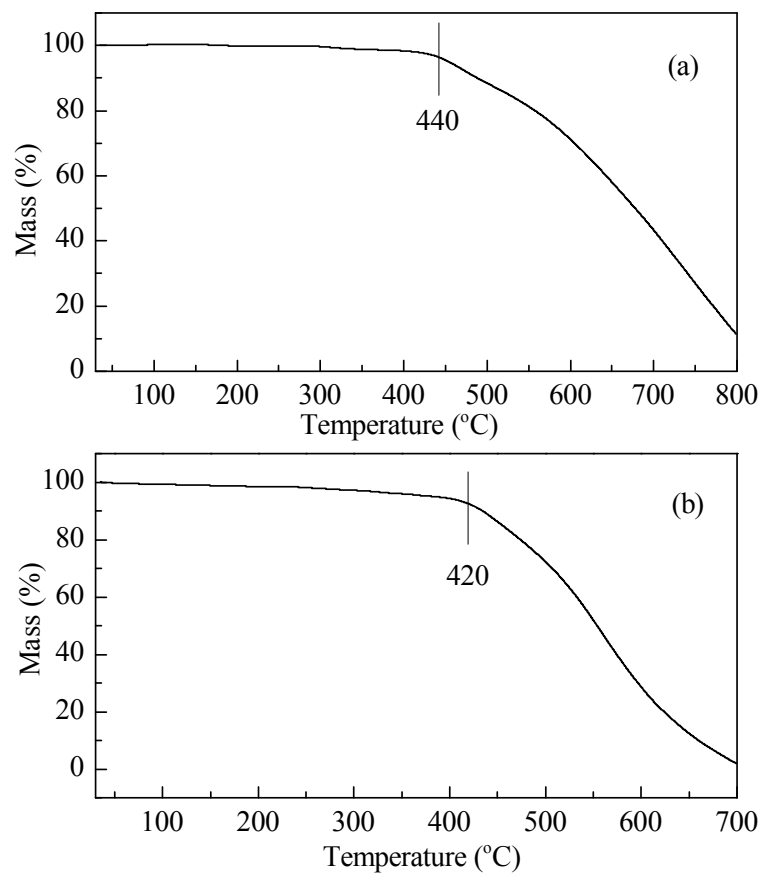

Fig. 3. TGA curves of COP-BIP in $\mathrm{N}_{2}$ (a) and artificial air $\left(\mathrm{N}_{2}: \mathrm{O}_{2}=4: 1\right)$ (b). Experiment conditions: ramp rate $10{ }^{\circ} \mathrm{C} / \mathrm{min}, \mathrm{N}_{2}$ flow speed 30 $\mathrm{mL} / \mathrm{min}$.

This inherent insolubility responsible for the desirable properties of the COP materials makes a detailed structural analysis difficult. MALDI-TOF mass spectrometry is used to characterize oligomers and can provide direct and unambiguous structural information [22]. We have reported the use of this technique in peptides analysis [23]. In this study, the slow mixing of the two monomer solutions generated oligomers during the initial reaction, and this could be analyzed by MALDI-TOF mass spectrometry. It is noteworthy that the precise structures of COP materials are seldom reported. In this study, the MALDI-TOF analysis confirmed the mass and thus helped to establish the COP-BIP structure. Because of the tendency of MALDI-TOF mass spectrometry to favor the ionization of lower molecular weight species, the spectra of these oligomers should not be considered to represent the true molecular weight distribution [24].
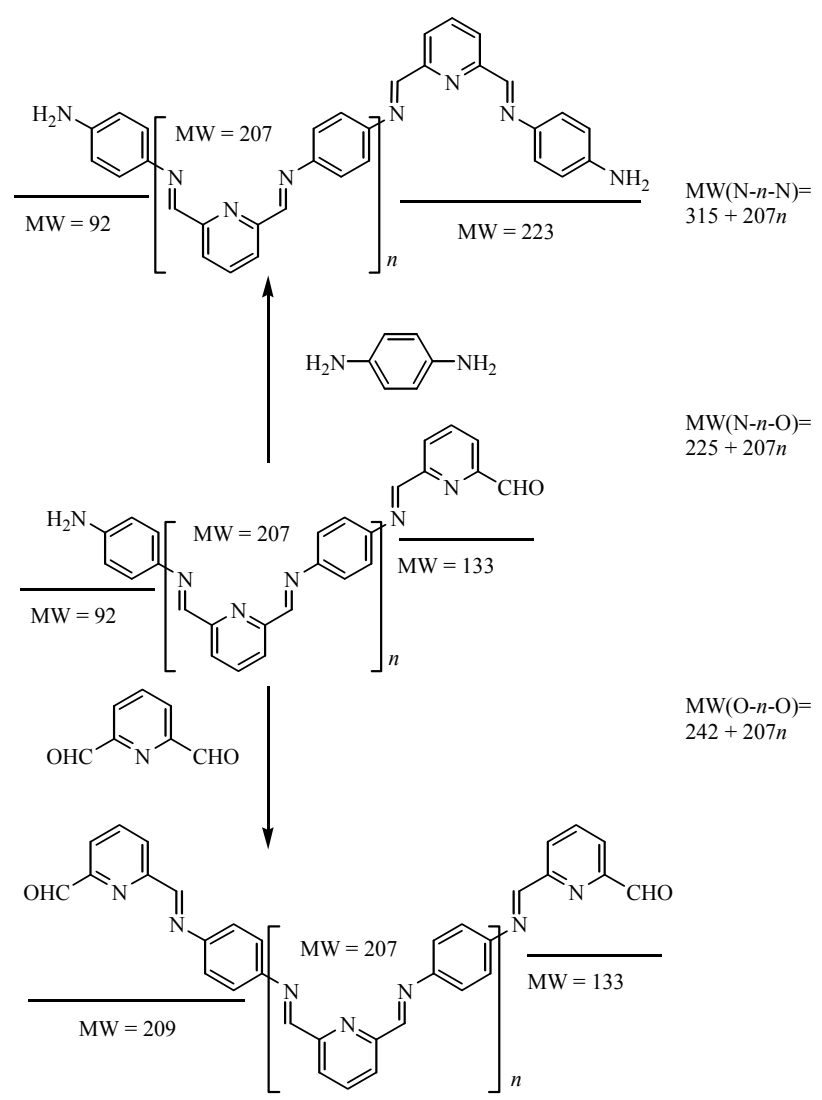

Scheme 2. Three types of conjugated COP-BIP chain and their calculated molecular weights. $\mathrm{N}$ indicates the $\mathrm{NH}_{2}$-terminated groups ( $\mathrm{MW}=$ 92 or 223), and $\mathrm{O}$ is the CHO-terminated groups (MW $=133$ or 209). $n$ indicates the number of repeat units in square brackets (MW = 207).

The mass spectra of the COP-BIP oligomers indicated that at a $m / z$ ratio less than 3000 it had distinctive peaks (Fig. 4(a)). Three series of single polymers were present with the same repeat unit of $207 \mathrm{~m} / \mathrm{z}$, which is the molar mass of the repeat unit (see square brackets in Scheme 2). Figure 4(b) shows an enlarged view of the $m / z$ ratio from 600 to 1000 . Two sets of peaks ( $n=2$ and 3, where $n$ is the number of the repeat unit) were differentiated by an interval of $207 \mathrm{~m} / \mathrm{z}$. These results agree well with the expected masses from the three different end-groups (Scheme 2 and Table 1). For $n$ increased to 1 above,
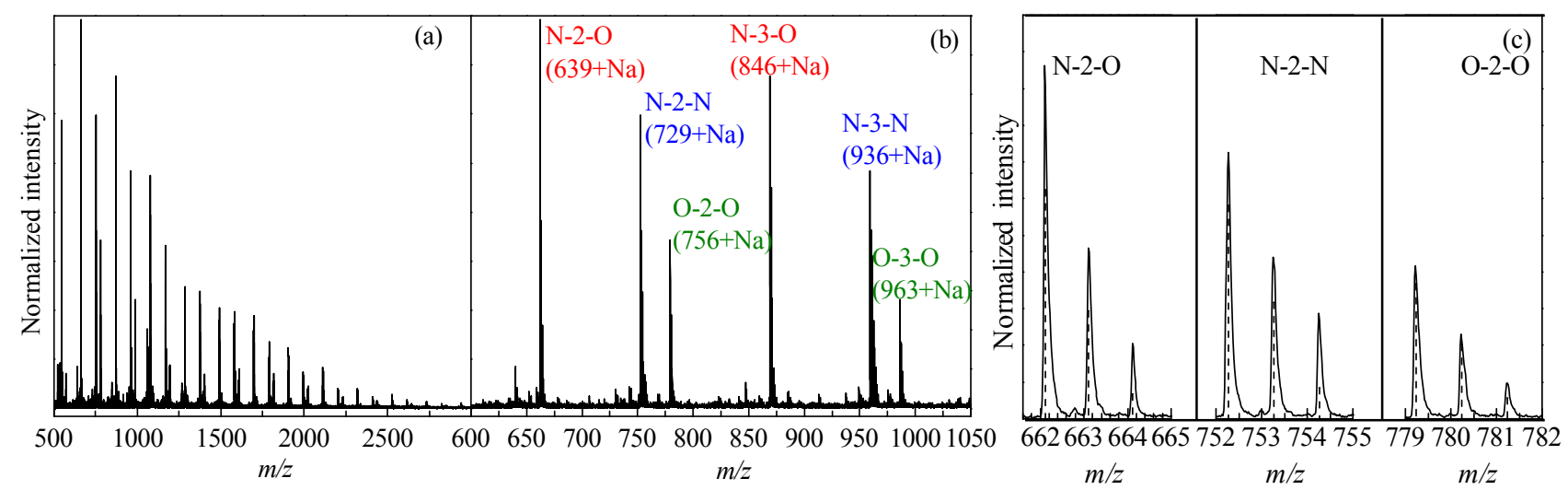

Fig. 4. (a) MALDI-TOF mass spectra of COP-BIP in the range of $m / z=500-3000$; (b) Enlarged view of the $m / z$ ratio from 600 to 1000 ; (c) Calculated (dashed line) and observed (solid curve) isotopic distributions for N-2-0, N-2-N, and 0-2-0. 
Table 1

Calculated mass signals of the oligomers with varying repeat units $n *$.

\begin{tabular}{lcccccccc}
\hline$n$ & 1 & 2 & 3 & 4 & 5 & 6 & 7 & $>7$ \\
\hline $\mathrm{N}-n-\mathrm{O}$ & - & 639 & 846 & 1053 & 1260 & 1467 & 1674 & $\ldots$ \\
$\mathrm{N}-n-\mathrm{N}$ & 522 & 729 & 936 & 1143 & 1350 & 1557 & 1764 & $\ldots$ \\
$\mathrm{O}-n-\mathrm{O}$ & 549 & 756 & 963 & 1170 & 1377 & 1584 & 1791 & $\ldots$ \\
\hline
\end{tabular}

* The table data show the maximum isotopic mass. The calculation was based on the formula shown in Scheme 2.

all the calculated mass spectra were found in the experimental MALDI-TOF (Table 1 and Fig. 4(a)). Oligomers of $\mathrm{N}-n-\mathrm{N}$ and $0-n-0$ can be viewed as exclusive $\mathrm{N}-n-0(225+207 n)$ reactions with 1,4-diamine benzene to form $\mathrm{N}-n-\mathrm{N}(315+207 n)$, and with 2,6-pyridinedicarboxaldehyde to form $0-n-0$ (342+ $207 n$ ), respectively. The isotopic distributions obtained experimentally by this technique are in good agreement with the predicted values (obtained by using the free software IsoPro 3.1 (a free 30 day evalutation version) written by M. Senko), as demonstrated for N-2-O, N-2-N, and 0-2-O in Fig. 4(c).

The unreacted end-groups of $-\mathrm{CHO}$ and $-\mathrm{NH}_{2}$ can further react with aniline and benzaldehyde, respectively, to form a benzene-terminated polymer under the same conditions, the so called "end-cap" [10]. This reaction can be used to gauge the amount of terminal amine and aldehyde groups in COP-BIP. End-capping of the -CHO groups can be clearly seen in the partially capped oligomers shown in Fig. 5(a). For example, the
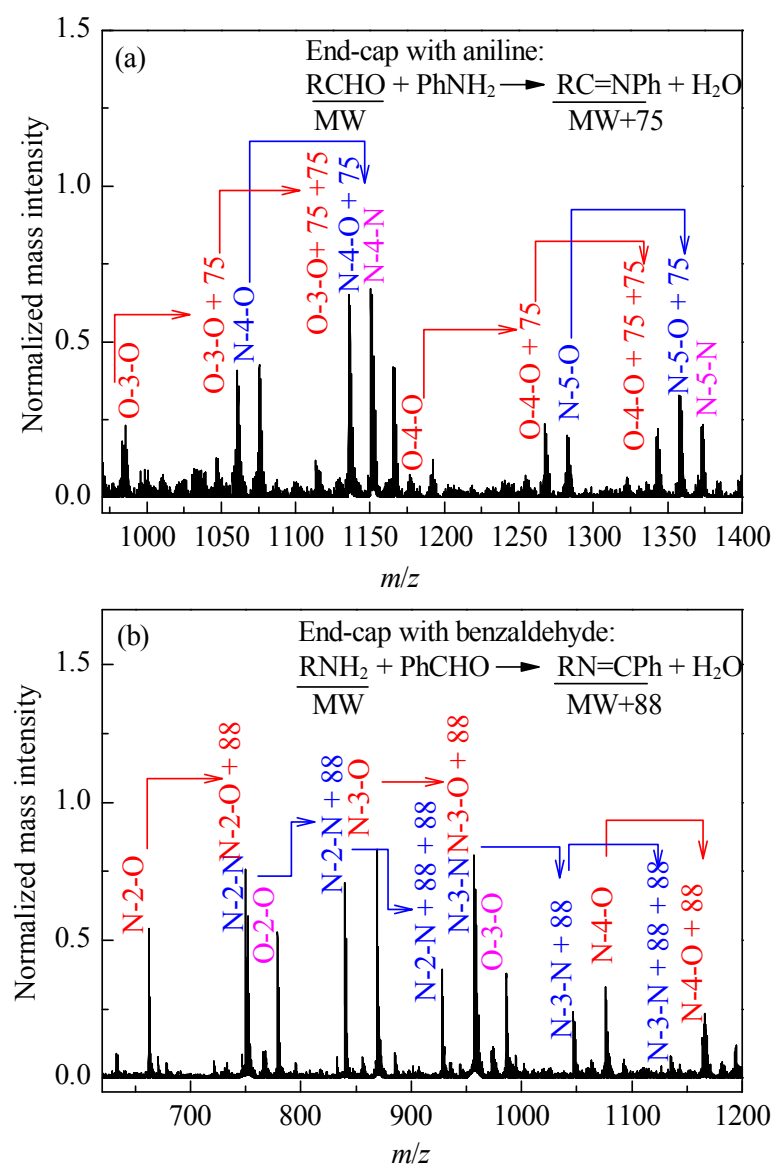

Fig. 5. (a) End-capping reaction with aniline. (b) End-capping with benzaldehyde. Note: $\mathrm{N}-2-\mathrm{O}+88(727 \mathrm{~m} / \mathrm{z})$ had a similar mass to $\mathrm{N}-2-\mathrm{N}$ $(729 \mathrm{~m} / \mathrm{z})$, and thus their isotopic partly overlapped.
0-3-0 oligomer $(963 \mathrm{~m} / \mathrm{z})$ has two -CHO groups at the ends. After reacting with aniline, it should increase its mass by 75 $m / z$, which was present as $(0-3-0+75,1083 \mathrm{~m} / z)$ in Fig. $5 a$. The oligomer $(0-3-0+75)$ reacted with aniline, and its mass was increased to $(0-3-0+75+75,1158 \mathrm{~m} / \mathrm{z})$. The same calculation rule was applied to the $\mathrm{N}-n-\mathrm{O}$ oligomers. No increase in mass caused by the $\mathrm{N}-n-\mathrm{N}$ oligomers was found in the MALDI-TOF analysis. The mass signal intensities increased as follows: $0-3-0<(0-3-0+75)<(0-3-0+75+75)$, indicating the end-capping approached completion although the MALDI-TOF analysis was semi-quantitative. Similar results were found when end-capping with benzaldehyde (Fig. 5(b)). The $\mathrm{N}-n-\mathrm{O}$ and $\mathrm{N}-n-\mathrm{N}$ oligomers were capped, and their mass increased by $88 \mathrm{~m} / \mathrm{z}$.

Bis(imino)pyridines, as binding sites, have many potential applications such as ligands for metal ions to produce catalysts. Herein, we prepared a Pd catalyst with bis(imino)pyridine as the ligand $\left(\mathrm{PdCl}_{2} / \mathrm{COP}-\mathrm{BIP}\right)$. It was prepared by soaking COP-BIP in a boiling $\mathrm{PdCl}_{2}$-acetonitrile solution for $6 \mathrm{~h}$. The catalyst was then washed three times with hot acetonitrile to remove weakly adsorbed $\mathrm{PdCl}_{2}$. Elemental analysis (Table 2) and TGA gave a comparable Pd weight content $(8.5 \%$ and $8.1 \%$, respectively), suggesting that about $20 \%$ of the bis(imino)pyridine coordinated with the $\mathrm{Pd}$ ion. The $\mathrm{PdCl}_{2}$ /COP-BIP catalyst showed similar thermal stability to COP-BIP (Fig. 6). The catalyst was evaluated in a SuzukiMiyaura $\mathrm{C}-\mathrm{C}$ coupling reaction, which is used in homogeneous media for the facile formation of C-C bonds (Table 3) [25]. Under reaction conditions less demanding than that reported in the literature for MOF and COP materials [2], the conversion of $p$-bromoanisole reached (confirmed by MS) $>99 \%$ with a selectivity for $p$-phenyl anisole of $>99 \%$ over the $0.16 \%$ Pd catalyst. The turnover number (TON) was calculated as 625, indi-

Table 2

Elemental analysis of COP-BIP and $\mathrm{PdCl}_{2} / \mathrm{COP}-\mathrm{BIP}$.

\begin{tabular}{lccccc}
\hline \multirow{2}{*}{ Sample } & \multicolumn{5}{c}{ Composition (wt\%) } \\
\cline { 2 - 6 } & $\mathrm{C}$ & $\mathrm{H}$ & $\mathrm{N}$ & $\mathrm{O}$ & $\mathrm{PdCl}_{2}$ \\
\hline COP-BIP & 73.44 & 4.58 & 19.96 & $2.02^{\mathrm{a}}$ & 0 \\
$\mathrm{PdCl}_{2} /$ COP-BIP & 62.97 & 4.02 & 17.02 & $1.73^{\mathrm{b}}$ & $14.16^{\mathrm{a}}$ \\
\hline
\end{tabular}

a Obtained by subtraction.

b Obtained by calculation: $73.44 / 62.97=2.02 / x, x=1.73$.

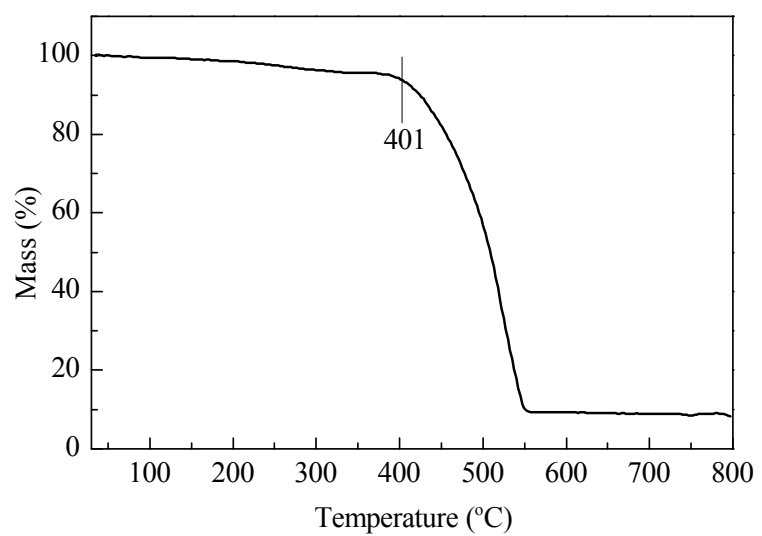

Fig. 6. TGA curve of $\mathrm{PdCl}_{2} / \mathrm{COP}-\mathrm{BIP}$ in artificial air $\left(\mathrm{N}_{2}: \mathrm{O}_{2}=4: 1\right)$. Experimental conditions: ramp rate $10^{\circ} \mathrm{C} / \mathrm{min}$, flow rate $30 \mathrm{~mL} / \mathrm{min}$. 
Table 3

$\mathrm{C}-\mathrm{C}$ coupling reaction over the $\mathrm{PdCl}_{2} / \mathrm{COP}-\mathrm{BIP}$ catalyst.

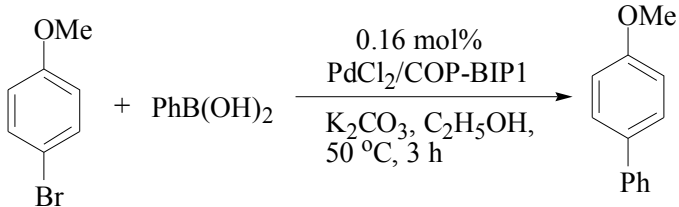

\begin{tabular}{lc} 
conversion $>99 \%$ & selectivity $>99 \%$ \\
\hline Recycle time & Yield (\%) \\
\hline Fresh & 99 \\
1 & 93 \\
2 & 97 \\
3 & 95 \\
\hline
\end{tabular}

cating that $\mathrm{PdCl}_{2} / \mathrm{COP}-\mathrm{BIP}$ possessed high catalytic activity during the catalysis of the Suzuki-Miyaura coupling reaction. The catalyst was filtered out and reused in the same reaction another three times without an apparent loss in catalytic activity (Table 4). No Pd leaching was detected in the reaction solution, which was confirmed by ICP analysis. The superior catalytic activity and catalyst stability of $\mathrm{PdCl}_{2} / \mathrm{COP}-\mathrm{BIP}$ are attributed to the bis(imino)pyridine ligands incorporated in the conjugated organic polymer.

\section{Conclusions}

We present an approach for the synthesis of a fully conjugated organic polymer (COP-BIP) and demonstrate a reliable method to determine its structure. The COP-BIP material benefits from a cheap and straightforward strategy, in contrast to the expensive and elaborate protocols previously reported. The COP-BIP polymer containing bis(imino)pyridine ligands may find wide application in catalysis, adsorption, and photochemistry.

\section{References}

[1] Hartley C S, Elliott E L, Moore J S. J Am Chem Soc, 2007, 129: 4512

[2] Ding S Y, Gao J, Wang Q, Zhang Y, Song W G, Su C Y, Wang W. J Am Chem Soc, 2011, 133: 19816

[3] Ding X S, Guo J, Feng X, Honsho Y, Guo J D, Seki S, Maitarad P, Saeki
A, Nagase S, Jiang D L. Angew Chem Int Ed, 2011, 50: 1289

[4] Wan S, Guo J, Kim J, Ihee H, Jiang D L. Angew Chem Int Ed, 2008, 47: 8826

[5] Wan S, Guo J, Kim J, Ihee H, Jiang D L. Angew Chem Int Ed, 2009, 48: 5439

[6] Spitler E L, Colson J W, Uribe-Romo F J, Woll A R, Giovino M R, Saldivar A, Dichtel W R. Angew Chem Int Ed, 2012, 51: 2623

[7] Bunck D N, Dichtel W R. Angew Chem Int Ed, 2012, 51: 1885

[8] Schwab M G, Fassbender B, Spiess H W, Thomas A, Feng X L, Mullen K. J Am Chem Soc, 2009, 131: 7216

[9] Choi S H, Risko C, Delgado M C R, Kim B, Bredas J L, Frisbie C D. J Am Chem Soc, 2010, 132: 4358

[10] Pandey P, Katsoulidis A P, Eryazici I, Wu Y Y, Kanatzidis M G, Nguyen S T. Chem Mater, 2010, 22: 4974

[11] Uribe-Romo F J, Hunt J R, Furukawa H, Klöck C, O’Keeffe M, Yaghi O M. J Am Chem Soc, 2009, 131: 4570

[12] Uribe-Romo F J, Doonan C J, Furukawa H, Oisaki K, Yaghi O M. J Am Chem Soc, 2011, 133: 11478

[13] Jiang J X, Wang C, Laybourn A, Hasell T, Clowes R, Khimyak Y Z, Xiao J L, Higgins S J, Adams D J, Cooper A I. Angew Chem Int Ed, 2011, 50: 1072

[14] He S, Buelt A A, Hanley J M, Morgan B P, Tennyson A G, Smith R C. Macromolecules, 2012, 45: 6344

[15] Biswal B P, Chandra S, Kandambeth S, Lukose B, Heine T, Banerjee R. J Am Chem Soc, 2013, 135: 5328

[16] Araujo C M, Doherty M D, Konezny S J, Luca O R, Usyatinsky A, Grade H, Lobkovsky E, Soloveichik G L, Crabtree R H, Batista V S. Dalton Trans, 2012, 41: 3562

[17] Tondreau A M, Lobkovsky E, Chirik P J. Org Lett, 2008, 10: 2789

[18] Trovitch R J, Lobkovsky E, Bill E, Chirik P J. Organometallics, 2008, 27: 1470

[19] Hojilla Atienza C C, Bowman A C, Lobkovsky E, Chirik P J. J Am Chem Soc, 2010, 132: 16343

[20] Du W M, Wang Q F, Yu Z K. Chin J Catal (杜旺明, 王清福, 余正坤。 催化学报), 2013, 34: 1373

[21] Ma J P, Wang M, Du Z T, Chen C, Gao J, Xu J. Polym Chem, 2012, 3: 2346

[22] Behrendt J M, Benstead M, Chaplin A, Wilson B, Turner M L. Macromolecules, 2011, 44: 9054

[23] Qin H Q, Gao P, Wang F F, Zhao L, Zhu J, Wang A Q, Zhang T, Wu R A, Zou H F. Angew Chem Int Ed, 2011, 50: 12218

[24] Wu K J, Odom R W. Anal Chem, 1998, 70: 456a

[25] Zhang M M, M M Jiang, Liang C H. Chin J Catal (张明明, 江曼曼, 梁 长海. 催化学报), 2013, 34: 2161

\section{Graphical Abstract}

Chin. J. Catal., 2014, 35: 540-545 doi: 10.1016/S1872-2067(14)60021-8

\section{Imine-linked conjugated Oorganic polymer bearing bis(imino)pyridine ligands and its catalytic application in $\mathrm{C}-\mathrm{C}$ coupling reaction}

Guifu Chen, Feng Wang*, Yehong Wang, Xiaochen Zhang, Hongqiang Qin, Hanfa Zou, Jie Xu*

Dalian Institute of Chemical Physics, Chinese Academy of Sciences; Graduate University of Chinese Academy of Sciences

A conjugated organic polymer linked by imine bonds bearing bis(imino)pyridine (COP-BIP) was synthesized for the first time. The formation process and the precise structure was determined by MALDI-TOF mass spectrometry. COP-BIP showed highly thermal stability up to $440{ }^{\circ} \mathrm{C}$ and was insoluble in conventional solvents. It functioned as a ligand for Pd ion and formed a heterogeneous catalyst during the Suzuki-Miyaura C-C coupling reaction.

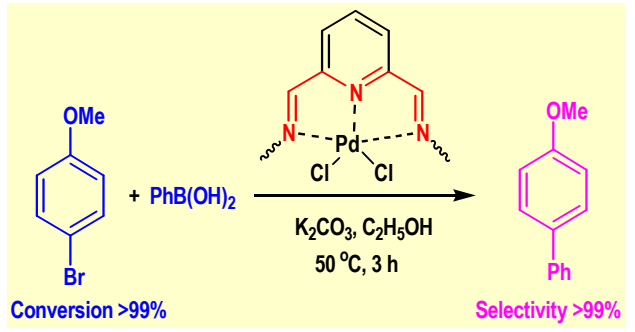




\title{
一种嵌有双亚胺基吡啶配体的全共轭有机聚合物材料及其 在 $\mathbf{C}-\mathrm{C}$ 偶联反应中的应用
}

\author{
陈贵夫 ${ }^{\mathrm{a}, \mathrm{b}}$, 王 峰 ${ }^{\mathrm{a},{ }^{*}}$, 王业红 ${ }^{\mathrm{a}}$, 张晓辰 ${ }^{\mathrm{a}}$, 秦洪强 ${ }^{\mathrm{a}}$, 邹汉法 ${ }^{\mathrm{a}}$, 徐 杰, ${ }^{\mathrm{a}, \#}$ \\ a中国科学院大连化学物理研究所, 辽宁大连116023 \\ ${ }^{\mathrm{b}}$ 中国科学院大学, 北京 100049
}

\begin{abstract}
摘要: 报道了一种嵌有双亚胺基吡啶配体的全共轭有机聚合物材料. 该材料所具有的双亚胺基吡啶配体起到链接聚合物单元和 络合金属中心的双重作用. 采用紫外可见光谱、红外光谱以及基质辅助激光解吸电离飞行时间质谱等对其结构进行了详细表征 和确认. 由于具有全共轭结构, 该材料的热稳定性达到 $440{ }^{\circ} \mathrm{C}$, 并且在常规溶剂中较难溶解. 作为多相催化剂载体, 可以络合 $\mathrm{Pd}$ 离 子形成新的多相配位催化剂, 在经典的Suzuki-Miyaura C-C偶联反应中转化率和选择性均达到 $99 \%$.

关键词: 共轭有机聚合物; 双亚胺基吡啶配体; 催化; Suzuki-Miyaura反应
\end{abstract}

收稿日期: 2013-11-01. 接受日期: 2014-01-06. 出版日期: 2014-04-20.

*通讯联系人. 电话/传真: (0411)84379762; 电子信箱: wangfeng@dicp.ac.cn

\#通讯联系人. 电话/传真: (0411)84379245; 电子信箱: xujie@dicp.ac.cn

基金来源：国家自然科学基金(21073184, 21273231); 中国科学院“百人计划”.

本文的英文电子版由Elsevier出版社在ScienceDirect上出版(http://www.sciencedirect.com/science/journal/18722067). 